\title{
Reivindicações Imediatas do Municipalismo em São Paulo
}

A criação da Secretaria do Interior representaria o primeiro passo no sentido da solução das dificuldades com que lutam os municípios paulistas

\section{A. S. DA Cunha Bueno}

(Secretário do Govêrno do Estado de São Paulo)

C

omo estudioso do Municipalismo, cujos ideais têm sido a preocupação principal de minha luta política, tenho apreciado a dedicação posta pelo DASP na explanação dos problemas com que lutam os Municípios brasileiros, e louvơ sem restrições o empenho que vem revelando êsse órgão da Presidência da República na divulgação de magníficos trabalhos tendentes não só a esclarecer os múltiplos aspectos da atualíssima questão, mas tambem, e principalmente, a ordenar melhor no Brasil inteiro, os esforços que estamos na obrigação de desenvolver para tirar as administrações municipais do marasmo em que se encontram.

Tenho observado, em minhas peregrinações pelo interior, e não só em São Paulo como, mais esporàdicamente, em outros Estados da União, os progressos que se têm alcançado ùltimamente na compreensão dos problemas municipais, sôbre os quais reinava antigamente extrema confusão perturbando, tumultuando, anulando as medidas tomadas aqui e ali para a sua solução, e que por falta de unidades não raro se chocavam umas contra as outras, com desnecessário e pernicioso desperdício de energia e recursos financeiros. Os Congressos de Municípios, conjugando estudiosos de quase duas mil entidades de govêrno local, têm contribuído poderosamente. por certơ, para o conhecimento aprofundado da composição política econômica, administrativa e social das comunas brasileiras. Mas sua repercussão e seus resultados teriam sido inegàvelmente bem menores, não fôsse o auxílio que thes prestou - Departamento Administrativo do Serviço Público levando ao conhecimento da Nação ơ que nêles se debateu ou resolveu, vulgarisando, assim noções mais seguras e realistas sôbre as necessidades e possibilidades municipais, habilitando a generalidade dos cidadãos a aquilatar a justiça do amparo dos órgãos centrais - da União e dos Estados - às administrações comunais .

Em parte, a projetada criação, em São Paulo, da Secretaria do Interior é resultado dessa feliz colaboração estabelecida entre o DASP e os Con- 
gressos de Municípios. Se. em alguns de seus aspectos essenciais, os Municípios brasileiros, e os de São Paulo, portanto, já conquistaram, pelas normas inscritas na Constituição e nas Leis, a autonomia política, em particular no que respeita à autonomia administrativa muito há ainda a corrigir no aspecto referente à autonomia financeira, cujas falhas constituem presentemente o maior obstáculo oposto à normal produtividade das administrações comunais. Realmente, se, desde o Ato Adicional de 1834, no texto das nossas leis estão consubstanciados, em relação aos Municípios, postulados de cunho eminentemente liberal a imperfeita distribuição das rendas públicas entre a União os Estados e os Municípios torna inoperante, por ausência de base financeira, a autonomia administrativa do "agrupamento antropogeográfico fundamental", que é o Município. Ora, sendo o Município a base da organização política e administrativa da Nação, essa falha perturba profundamente tôda a vida nacional.

Quem quer que percorra o interior do País - e êsse contraste é particularmente chocante em São Paulo - distingue perfeitamente. pela apurada técnica e fartura de recursos de umas, e pela modéstia e imperfeição de outras, as obras públicas a cargo da União e dos Estados de um lado, e dos Municípios de outro. Acresce que os serviços públicos da atribuição dêstes são não apenas claudicantes, mas também insuficientes. Nãơ só isso: inexístem mesmo, na maioria dos Municípios, obras indispensáveis, ao bem-estar coletivo e serviços públicos sem os quais seria utópico pensar no desenvolvimento econômico do País. Passam assim a vacilar pela própria fraqueza das bases, as possibilidades do progresso nacional.

Tudo isso porque, sofrendo as consequêencias da imperfeita distribuição das rendas públicas, a autonomia municipal se tornou puramente jurídica a formal. Isto é, soube o legislador, em atenção às nossas tendências e tradições liberais, caminhar no sentido da descentralização administrativa do País, conferindo às administrações comunais, funções perfeitamente condizentes com êsse ideal, e com essa necessidade. Mas, esquecendo-se de garantir-lhes também a autonomia financeira, ou seja os recursos materiais que as habilitassem ao normal cumprimento de tão alta missão, deram na verdade um passo atrás nessa promisora evolução, fortalecendo a centralização administrativa o que representa um clamoroso absurdo em país da extensão e das peculiaridades do nosso.

Já não há no Brasil quem não compreenda a necessidade da melhor distribuição das receitas fiscais, de modo a possibilitar a normal atividade das administrações municipais. O assunto, porém, nãơ é de fácil solução, e nem se recomenda que hajamos nesse domínio sem longa meditação, sem o estudo demorado da questão, a fim de que, ao tentarmos vestir um santo, não acabemos por desvestir os demais, transferindo para a União e para os Estados as dificuldades com que ora lutam os Municípios. O que se impõe é uma distribuição verdadeiramente equitativa tendo-se em conta a multiplicidade e a importância das atribuições de uns e outrơs.

Em todo caso, reconhecendo a atual disparidade, tanto a União quanto os Estados vêm procurando reservar parte de suas disponibilidades para auxílios mais urgentes aos Municípios. O Tesouro paulista, por exemplo, se 
tem disposto às vêzes mesmo a sacrifícios para ajudar as atividades municipais, mas ainda assim sem dêles obter todos os resultados que, em benefício da eoletividade. dêles se poderiam esperar. Houve, ademais, no passado, criticáveis desvios no sentido dessa colaboração, que passou a servir a interêssez partidários e pessoais, jungindo Municípios necessitados de ajuda financeira a inconfessáveis interêsses políticos dos governos estaduais e das agremiaçóes partidárias governistas. Era, realmente, como favor a correligionários do Interior que se distribuiam, sem plano nem equidade, êsses auxílios havendo administrações municipais que recebiam muito, e outras nada, agravando a disparidade entre as realizações das diferentes comunas estaduais. Além de tudo, os prefeitos e vereadores do Interior se transformavam em pedintes, povoando permanentemente os corredores do Palácio do Govêrno na postura humilhante de quem necessitava mendigar, de chapeu na mão, a munificência estadual.

Tudo isso, e o mais que seria fastidioso enumerar aqui, é o que o Govérno do Sr. Jânio Quadros procura corrigir com a criação da Secretaria do Interior, mediante a transformação da atual Secretaria do Govêrno, de cuja pasta sou titular, num órgão que se encarregue, precipuamente, da assistência aos Municípios, prevista nas leis básicas da Nação e do Estado. O ponto básico dessa transformação consistirá na criação do Departamento de Assistência aos Municípios, com o fim de encaminhar e processar, perante as Secretarias competentes. nos têrmos da Lei Orgânica dos Municípios, os assuntos que devam ser submetidos à consideração do Chefe do Govêrno, incluindo aquêle referente às nomeações dos prefeitos das Estâncias e orientação de seus serviços a cargo do Estado. "Através dêsse órgão especializado - diz o Sr. Governador Jânio Quadros - que viza coordenar e sistematizar os problemas municipais, poderá o Govêrno realizar os seus fins com maior facilidade, atendendo, sobretudo. à conveniência do bem público".

$\mathrm{Na}$ parte da assistência, seja financeira, seja técnica ou administrativa. êsse projeto visa a atender em quase tudo, dentro dos recursos estaduais, o que se reivindicou nesse terreno nos Congressos de Municípios já realizados no Brasil. E note-se que a preocupação máxima do Govêrno do Estado nesse ato será assegurar efetivamente a autonomia, a independência municipal, amparando os Municípios como quem cumpre um dever estabelecido pelas leis e não como quem faz um favor a amigos e correligionários. Com a criação da Secretaria do Interior, estará definitivamente ultrapassada essa fase de arbítrios na distribuição dos auxílios aos Municípios. Doravante, tudo obedecerá a planos prèviamente traçados e pùblicamente debatidos, visando-se única e exclusivamente as mais altas aspirações coletivas, sem segundas intenções pessoais nem preocupações subalternas. A parte mais admirável dêsse programa, tendo-se em vista as aperturas financeiras do momento, é que o Govêrno de São Paulo pretende promover essa revolução no sistema de assistência municipal, sem gravar de novos ônus o Erário. Realmente, a transformação da Secretaria do Govêrno em Secretaria do Interior se fará sem novas despesas, e não se pretende, neste instante, ampliar $\sigma$ volume dos recursos financeiros postos à disposição das Municipalidades. O que se multiplicará, é o trabalho dos técnicos que o Estado já possui, e que serão pos- 
tos a serviço dos interêsses municipais, assegurandơ aos Municípios a assistência que êstes reclamam e planejando e executando cautelosamente as obras públicas da competência comunal.

O assunto é vasto demais para que se possa. num trabalho dêste caráter e desta extensão, analisar tôda a obra que com a nova Secretaria do Interior se pretende realizar. Basta, porém, assinalar que com essa iniciativa o Govêrno de São Paulo pretende firmar as bases da autonomia financeira e administrativa municipal, para que todos a encarem com simpatia. E' o melhor que se poderá fazer, até que as leis corrijam definitivamente as falhas que comprometem a vida municipal, assegurando. principalmente, às suas administrações os recursos fiscais de que precisam para o cumprimento de sua altíssima missão na comunidade nacional. Não tenho dúvida em afirmar que se êste exemplo encontrar seguidores em outros Estados, estará pràticamente encaminhada a solução dos problemas municipalistas do País.

$\mathrm{Na}$ ausência de definição das atribuições, é fato comum encontrarem-se no serviço público federal, funcionários desempenhando atribuições completamente estranhas ao cargo, algumas de natureza mais complexa e outras, pelo contrário, bem mais simples e elementares. Os levantamentos realizados mostraram a verdadeira extensão dêsse problema. Tantos e tão numerosos são êsses casos que não seria possível, através de simples enquadramento, a solução de todos êles.

(Trecho do relatório da Comissão de Cargos, 1954) 